\title{
In vitro evaluation of the shear bond strength between fiber posts and methacrylate or silorane based composite resins
}

\author{
Pedro José Andrade da Silva ${ }^{1 *}$, Roberta Tarkany Basting Hoffing ${ }^{1}$, Flávia L. B. do Amaral ${ }^{1}$, Cecília P. Turssi ${ }^{1}$, \\ Carlos Eduardo Sabrosa Borges da Silva ${ }^{2}$ and Fabiana Mantovani Gomes França ${ }^{1}$
}

\section{${ }^{*}$ Correspondence:}

pjora@ig.com.br

${ }^{1}$ São Leopoldo Mandic Institute and Dental Research

Center, Rua José Rocha Junqueira, 13, Ponte Preta, Campinas, SP 13045-755, Brazil

Full list of author information is available at the end of the article

\begin{abstract}
:
Fiber posts (FP) are commonly used for extensive coronal reconstructions, often being associated with composite resins (CR) in order to minimize the space between the post and the intraradicular dentin. This study evaluated the shear bond strength of three different CR to a FP surface, with and without FP pretreatment with adhesive. Sixty \#3 FP (Exacto Translúcido) were divided into six experimental groups $(n=10)$, according

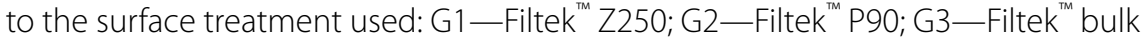
fill restorative; G4-Scotchbond ${ }^{\text {Tm }}$ Universal adhesive + Filtek ${ }^{\text {Tm }}$ Z250; G5-Silorane adhesive + Filtek $^{\text {Tm }}$ P90 and G6-Scotchbond ${ }^{\text {tm }}$ Universal adhesive + Filtek ${ }^{\text {TM }}$ Bulkfill restorative. Two $2.0 \mathrm{~mm}$ thick specimens were obtained from each fiber post unit and submitted to a push-out test in a universal testing machine with a $5 \mathrm{~mm} / \mathrm{min}$ crosshead speed and 5 Kilo-newton load cell. Mean and standard deviation values for bond strength (MPa) were: G1: $5.54 \pm 1.78 ; \mathrm{G} 2: 1.69 \pm 1.02 ; \mathrm{G} 3: 5.31 \pm 1.58 ; \mathrm{G} 4: 7.39 \pm 2.05$; G5: $6.07 \pm 1.88$ e G6: $5.50 \pm 3.03$. The results were analyzed through two-way analysis of variance (ANOVA) and statistical significant differences were determined by Tukey test $(p=0.05)$. When no adhesive was used, the bond strength was statistically significantly higher for $\mathrm{G} 1$ and $\mathrm{G} 3$, which were not statistically significantly different between them. Adhesive application showed statistically significantly higher bond strength only for G5. Without the FP pretreatment with adhesive, the bond strength was statistically significantly higher for the methacrylate-based resins and the FP pretreatment with adhesive increased the bond strength only for the silorane-based resin and changed the prevalence of failure mode type to cohesive in all composite resin study groups. The use of silorane-based composite resins to customize posts require the use of adhesive as FP surface pretreatment. The use of adhesive as pretreatment of simulated customized FP, regardless of the CR used, appear to improve the mechanical behavior of the FP-CR unit.
\end{abstract}

Keywords: Post and core technique, Composite resins, Silorane resins, Reinforced fiber post, Esthetic core 


\section{Background}

FP are used to aid the retention of restorative materials in endodontically treated teeth with severe destruction $[1,2]$. In some clinical situations, the space between the FP and the walls of the root canal may be too wide due to the root canal anatomy and/or treatment $[1,3,4]$. As the thickness of the composite resin cement directly influences the FP adaptation and consequently the bond strength [3, 4], thinner cement layers are desirable for better mechanical properties [5, 6]. In addition, the greater the space between FP and the root canal wall, the greater chance for catastrophic root fractures [7] due to eventual post loosening. There are two techniques proposed in the literature to minimize this space, the use of accessory fiber posts $[8,9]$ and customization of the fiber post with CR [10-12]. The purpose of both techniques is to reduce the effect of shrinkage stress associated with CR cements, obtaining a more stable adhesive interface [10-13].

CR can be used to fill in this space as well as the core build up material $[1,14-16]$. The vast majority of methacrylate-based CR has polymerization shrinkage between 2 and $5 \%$ [17], whereas silorane-based CR exhibits polymerization shrinkage below $1 \%$ [18, 19], which would make the adaptation of the post to the root canal better.

New CR materials have been developed to be used in thicker increments either as an intermediate layer in composite resin restorations or as the final restorative material. A photoactive group was added to these to control the kinetic of the polymerization and also a polymerization modulator in the center of the dimethacrylate urethane monomer, increasing the monomer size compared to regular restorative CR. This modification reduces the polymerization shrinkage compared to the flowable and packable methacrylate-based CR [20,21]. This CR is used to simplify the incremental technique and reduce clinical hours, with up to $4 \mathrm{~mm}$ increment thickness [22, 23]. The depth polymerization capability and lower polymerization shrinkage of this group of composite resins could aid in obtaining the most root-wall-fit personalization of the fiber post within the customization post technique, guarantying the thinner cement layer possible (Table 1).

Several studies have evaluated the shear bond strength between customized FP and dentin [24-27]. However the fracture patterns are usually about failures in adhesion between post and resin material, either composite or resin cement [3, 28]. In that matter, different surface treatments have been described, such as silanization and application of an adhesive system [3, 4, 28-32], to ensure the bond between the resin-based materials and FP. However, for the customized-post technique there are not enough studies to determine if the adhesive use in the preparation of FP surface is actually required [33, 34].

Therefore, the current study evaluated the bond strength of silorane-based, a bulkfill methacrylate-based and a conventional methacrylate-based CR to a fiber post, with and without the use of adhesive systems.

The null hypothesis was that there was no difference on the shear bond strength between FP and tested CR, regardless of adhesive application.

\section{Methods}

\section{Specimen preparation}

FP were divided into 06 (six) groups, cardinally numbered, from 1 to 6, with 10 (ten) posts each, according to the surface treatment and CR selected, as shown in Table 2. The sample size was based on literature [35, 36]. 
Table 1 Materials, manufacturer, composition and application

\begin{tabular}{|c|c|c|}
\hline Material/manufacturer & Composition & Application \\
\hline $\begin{array}{l}\text { Filtek }^{\mathrm{TM}} \text { Z250, A2 Shade, } \\
\quad 3 \text { M/ESPE }\end{array}$ & $\begin{array}{l}\text { 75-85 \% silanized ceramic; } 1 \text {-10\% BISEMA6; } 1-10 \% \\
\text { UDMA; } 1-10 \% \text { BIS-GMA; }<5 \% \text { TEGDMA; }<5 \% \\
\text { aluminum oxide; }<0.5 \% \text { benzotriazole; }<0.2 \% \\
\text { EDMAB }\end{array}$ & $\begin{array}{l}2.5 \mathrm{~mm} \text { maximum incre- } \\
\text { ment, photo-activated } \\
\text { for } 80 \mathrm{~s}\end{array}$ \\
\hline $\begin{array}{l}\text { Filtek }^{\mathrm{TM}} \text { P90, A2 Shade, } \\
3 \mathrm{M} / \mathrm{ESPE}\end{array}$ & $\begin{array}{l}\text { 5-15\% 3,4-epoxi-ciclohexil-ethyl-cyclopolimethyl- } \\
\text { siloxane; 5-15\% bis-3,4-epoxi-ciclohexil-ethyl- } \\
\text { fenil-methyl-silane; } 50-70 \% \text { silanized quartz; } \\
\text { 10-20\% Yttrium fluoride; camphorquinone }\end{array}$ & $\begin{array}{l}2.5 \mathrm{~mm} \text { maximum incre- } \\
\text { ment, photo-activated } \\
\text { for } 80 \mathrm{~s}\end{array}$ \\
\hline $\begin{array}{l}\text { Filtek }^{\mathrm{TM}} \text { Bulk Fill Restora- } \\
\text { tive, A2 Shade, } 3 \mathrm{M} / \\
\text { ESPE }\end{array}$ & $\begin{array}{l}\text { 60-70 \% silanized ceramic; } 10-20 \% \text { aromatic di } \\
\text { methacrylate urethane; } 1-10 \% \text { Ytterbium fluo- } \\
\text { ride; } 1-10 \% \text { UDMA; } 1-10 \% \text { silanized silica; }<5 \% \\
\text { DDDMA; }<5 \% \text { water; }<5 \% \text { silanized zirconium; } \\
<1 \% \text { modified methacrylate monomer; }<0.5 \% \\
\text { EDMAB; }<0.5 \% \text { benzotriazole }\end{array}$ & $\begin{array}{l}2.5 \mathrm{~mm} \text { maximum incre- } \\
\text { ment, photo-activated } \\
\text { for } 80 \mathrm{~s}\end{array}$ \\
\hline $\begin{array}{l}\text { Scotchbond }^{\mathrm{TM}} \text { Universal, } \\
3 \mathrm{M} / \mathrm{ESPE}\end{array}$ & $\begin{array}{l}\text { 15-25\% BIS-GMA; } 15-25 \% \text { HEMA; } 5-15 \% \text { deca } \\
\text { methylene di methacrylate; } 10-15 \% \text { ethanol; } \\
\text { 10-15\% water; } 5-15 \% \text { silanized silica; } 1-10 \% \\
\text { propenoic acid, 2-methyl, decanediole and } \\
\text { phosphoric anidryde byproducts; } 1-5 \% \text { itaconic } \\
\text { and acrylic co-polymer acids; }<2 \% \text { dimethyl } \\
\text { amine benzoate; }<2 \% \text { camphorquinone; }<2 \% \\
\text { dimethyl amine ethyl methacrylate; }<2 \% \text { methyl } \\
\text { ethyl ketone }\end{array}$ & $\begin{array}{l}\text { Application of a thin layer } \\
\text { for } 15 \mathrm{~s} \text {, Air drying for } 5 \mathrm{~s} \text {, } \\
\text { Light-curing for } 20 \mathrm{~s}\end{array}$ \\
\hline Filtek $^{\mathrm{TM}}$ P90 SA, 3 M/ESPE & $\begin{array}{l}\text { Primer: } 15-25 \% \text { HEMA; } 15-25 \% \text { BIS-GMA; 10-15 \% } \\
\text { water; } 10-15 \% \text { ethanol; 5-15\% phosphoric acid } \\
\text { methacryl-oxi-hexil-esters; 8-12 \% silanized silica; } \\
\text { 5-10\% 1,6-hexanediol di methacrylate; <5 \% ita- } \\
\text { conic and acrylic acid co-polymer; }<5 \% \text { (dimethyl } \\
\text { amine) ethyl methacrylate; }<3 \% \text { DL- camphorqui- } \\
\text { none; }<3 \% \text { phosphine oxide; Bond: } 70-80 \% \\
\text { replaced di methacrylate; 5-10\% silanized silica; } \\
\text { 5-10\% TEGDMA; }<5 \% \text { phosphoric acid meth- } \\
\text { acryl-oxi-hexil-esters; }<3 \% \text { DL-camphorquinone; } \\
\text { 1,6 hexanediol di methacrylate }\end{array}$ & $\begin{array}{l}\text { Homogenous bond applica- } \\
\text { tion, Light-curing for } 20 \mathrm{~s}\end{array}$ \\
\hline $\begin{array}{l}\text { Exacto Translúcido \#03, } \\
\text { Angelus }^{\circledR}\end{array}$ & $80 \%$ glass fiber, $20 \%$ epoxy resin & $\begin{array}{l}\text { Cleansing with ethanol } 70 \% \\
\text { for } 15 \mathrm{~s}\end{array}$ \\
\hline Silano Angelus ${ }^{\circledR}$ & $\begin{array}{l}\text { X-R-Si (OR) 3n, X: organic-functional group bonds } \\
\text { to composite resin, R: methylene group, OR: } \\
\text { hydrolysable group bonds with porcelains, } \\
\text { composite resins and glass fiber posts, Si: Silicium. } \\
\text { n: } 0-3\end{array}$ & $\begin{array}{l}\text { Thin layer application } 60 \mathrm{~s} \\
\text { waiting time Smooth air } \\
\text { drying for } 5 \mathrm{~s}\end{array}$ \\
\hline
\end{tabular}

BISEMA6 bisphenol a polyethylene glycol diether dimethacrylate; UDMA diurethane dimethacrylate; BISGMA bisphenol a diglycidyl ether dimethacrylate; TEGDMA triethylene glycol dimethacrylate: EDMAB ethyl 4-dimethyl aminobenzoate; $H E M A$ 2-hydroxyethyl methacrylate

Following manufacturer's instructions all FP were cleansed with a gauge embedded in ethanol $70 \%$ (Ciclofarma) for $10 \mathrm{~s}$ and treated with silane (Angelus ${ }^{\circledR}$ ). Following manufacturer recommendations, all FP were previously treated with silane (Angelus ${ }^{\circledR}$ ). In groups G4, G5 and G6, the FP was treated with the correspondent adhesive (Table 2), with a thin layer application, as recommended by the manufacturer, followed by air drying for $05 \mathrm{~s}$ in order to evaporate the solvent and homogenize the adhesive thickness and light curing with a light emitting diode (LED) (Elipar ${ }^{\mathrm{TM}}$ Paradigm $^{\mathrm{TM}} ; 3 \mathrm{M} / \mathrm{ESPE}$, Seefeld, Germany) for $20 \mathrm{~s}$.

Once treated, the FP was individually placed into a transparent plastic matrix (Fig. 1) specially designed to keep the posts in an up-right position, keeping them centralized and to standardize the CR filling procedure. The matrix was then, incrementally filled, 
Table 2 Experimental groups

\begin{tabular}{lll}
\hline Group & $\mathbf{N}$ & Surface treatment \\
\hline 1 & 10 & Filtek $^{\mathrm{TM}}$ Z250 filling \\
2 & 10 & Filtek $^{\mathrm{TM}}$ P90 filling \\
3 & 10 & Filtek $^{\mathrm{TM}}$ Bulk Fill Restorative filling \\
4 & 10 & Scotchbond $^{\mathrm{TM}}$ Universal adhesive application; Filtek Z250 filling \\
5 & 10 & Filtek $^{\mathrm{TM}}$ P90 silorane adhesive application; Filtek $^{\mathrm{TM}}$ P90 filling \\
6 & 10 & Scotchbond $^{\mathrm{TM}}$ Universal adhesive application; Filtek \\
\end{tabular}

leaving approximately $6.0 \mathrm{~mm}$ of the posts extremity free at the top and $1.0 \mathrm{~mm}$ at the bottom end and $2.0 \mathrm{~mm}$ of composite resin around the post. Each increment was inserted around the FP (Fig. 2) and condensed with a Teflon instrument (Fig. 3) and light cured 04 (four) times for $20 \mathrm{~s}$ each, with an $1200 \mathrm{~mW} / \mathrm{cm}^{2}$ irradiance LED (Elipar ${ }^{\mathrm{TM}}$ Para$\left.\operatorname{digm}^{\mathrm{TM}} ; 3 \mathrm{M} / \mathrm{ESPE}\right)$. All CR used were of A2 shade.

The posts involved with $\mathrm{CR}$ were removed from the plastic matrix and stored in distilled water for $24 \mathrm{~h}$ in an oven (ECB 3; Odontobrás, Ribeirão Preto, SP, Brazil) at $37{ }^{\circ} \mathrm{C}$. The FP-CR samples were then perpendicularly glued to an acrylic plate with wax (Asfer,
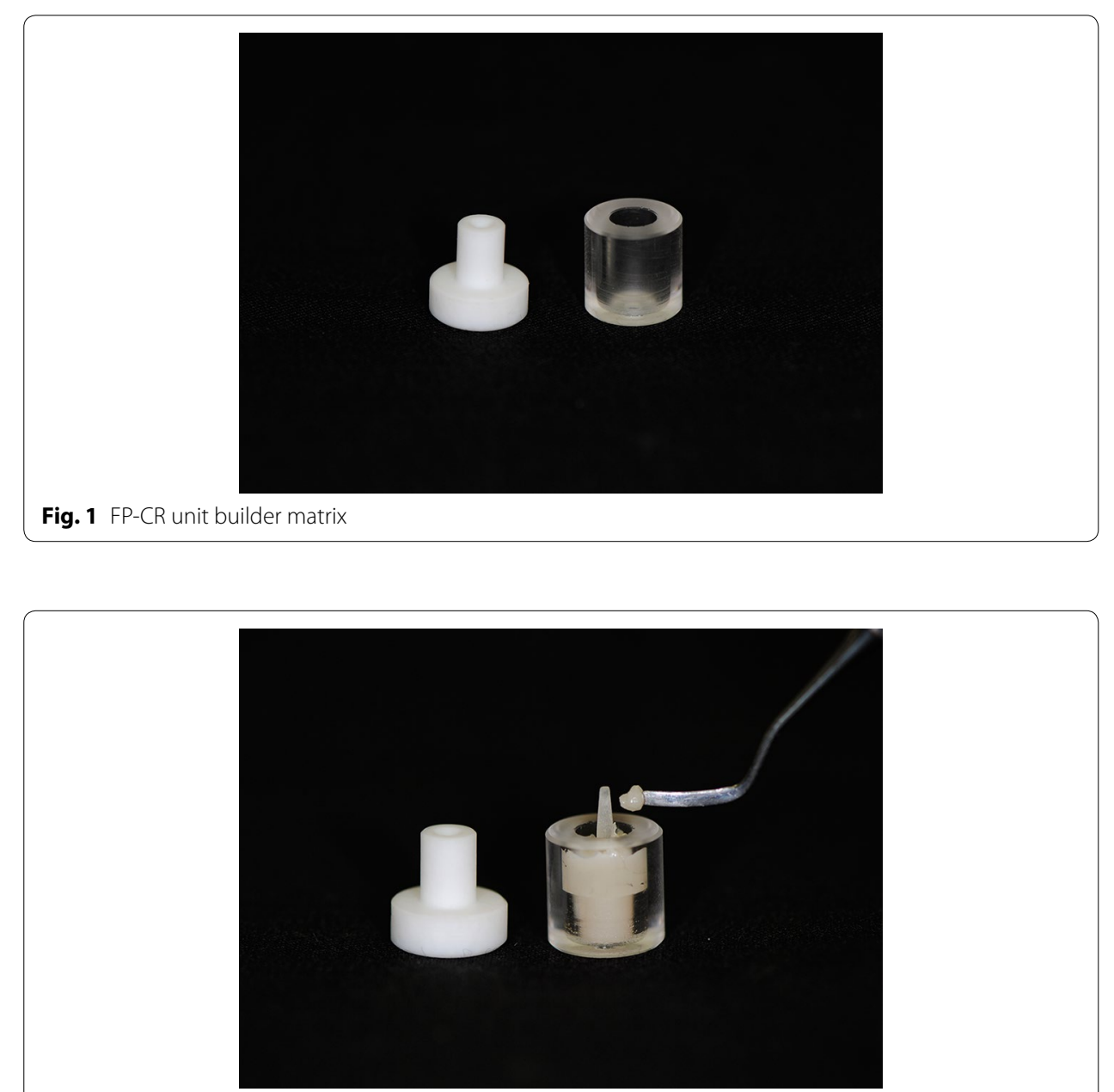

Fig. 2 CR increment filling 


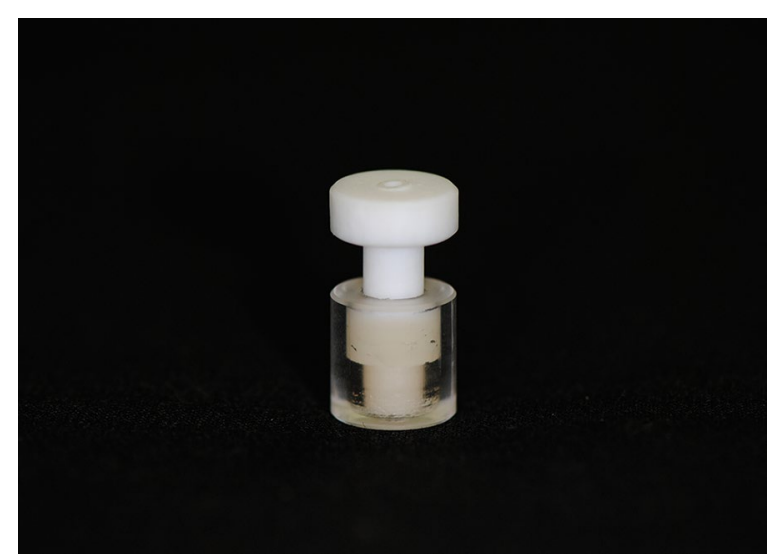

Fig. 3 CR condensing

São Caetano do Sul, SP, Brazil) and positioned in a precision cutter machine (IsoMet ${ }^{\mathrm{TM}}$ 1000; Buehler, Bluff, IL, USA). With a wafering diamond blade (11-4244 15HC; Buehler), three parallel cuts were made perpendicularly to the posts long axis (Fig. 4), obtaining two $2.0 \mathrm{~mm}$-thick testing specimens from each post (Fig. 5), resulting in 20 test samples for each experimental group. For each FP-CR sample, an average value for the bond strength was calculated from both test samples derived from it.

\section{Push-out test}

A stainless steel base was positioned on a universal testing machine (EZ test EZ-LX; Shimadzu Corporation, Suzhou, Sū, China) to perform the push-out test. This base had a $12.8 \mathrm{~mm}$ diameter-wide table designed to receive a second stainless steel base that was prepared to receive the test samples. This second base had a $2.5 \mathrm{~mm}$ diameter-wide orifice in the center and was fabricated to allow the post to drop into it during testing. All samples were loaded with the bottom part of the post facing up.

A metallic arm, with an $1 \mathrm{~mm}$ diameter active tip attached to the load cell (5 Kilonewton), was aligned to the first metal base so its active tip would only touch the post

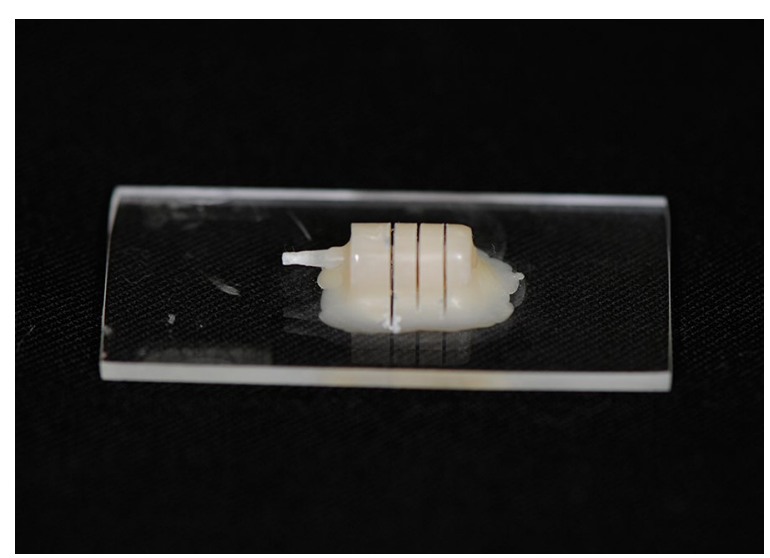

Fig. 4 FP-CR unit cuts 


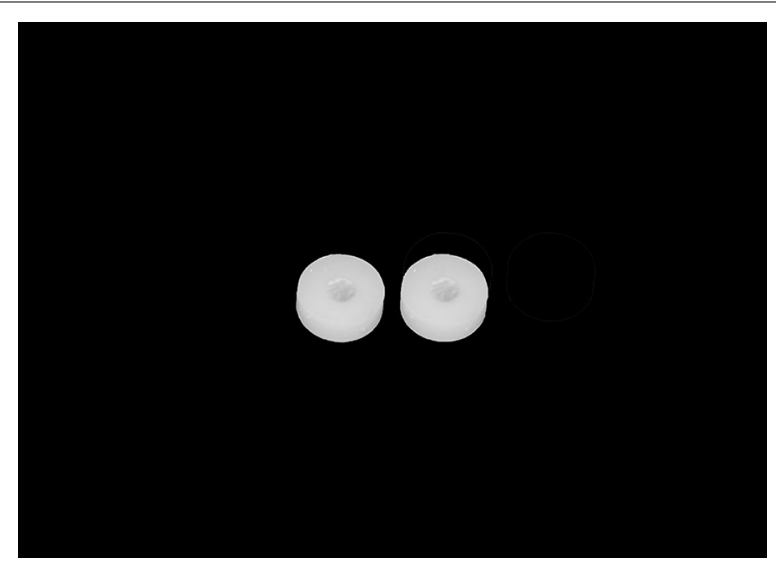

Fig. 5 Testing specimens

during testing. The push-out test was performed with a crosshead speed of $0.5 \mathrm{~mm} / \mathrm{min}$ until automatic detection of failure (Fig. 6).

The shear bond strength values in Mega Pascal (MPa) were obtained by dividing the maximum force needed to dislodge the post, in Newton $(\mathrm{N})$, by the adhesive interface area. The area was calculated through the diameters of the post and the thickness of the specimen. Therefore, the area $=\left\{[\pi(\mathrm{R}+\mathrm{r})] \cdot\left[\mathrm{h}^{2}(\mathrm{R}-\mathrm{r})^{2}\right]^{0.5}\right\}$, where $\pi$ is constant and equals 3.1416; $R$ represents the radius of the top part of the post, $r$ is the radius of the bottom part of the post and $h$ represents the height of the post section, in $\mathrm{mm}$.

The values were recorded and submitted to statistical analysis.

\section{Failure mode}

After the push-out test, all specimens were observed under a stereoscopic loupe (Eikonal, São Paulo, SP, Brazil) with $40 \times$ magnification, to determine the failure mode, divided as: (1) adhesive failure between post and resin; (2) mixed failure and (3) cohesive failure within post and resin.

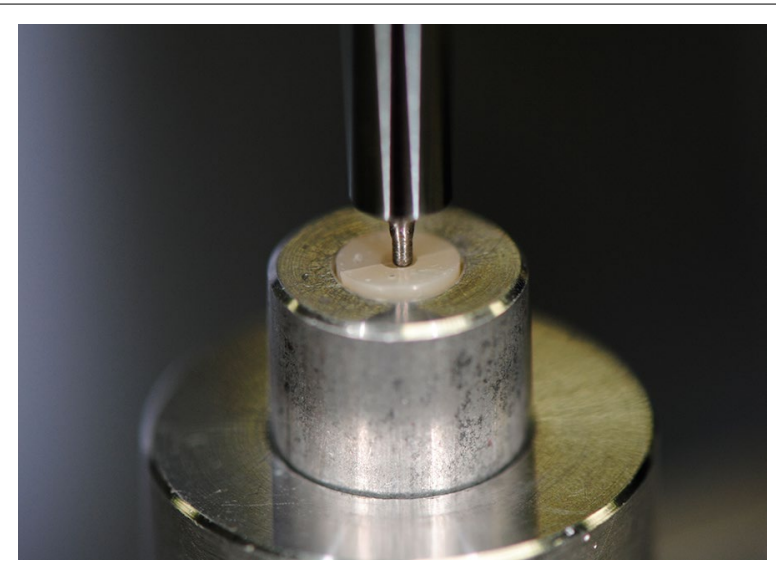

Fig. 6 Specimen failure during push-out testing 


\section{Statistical analysis}

The results gathered for the shear bond strength are expressed by average and standard deviation and were submitted to two-way ANOVA testing and for average multiple comparisons Tukey post hoc test was employed. Significance level was set at $5 \%$.

\section{Results}

Two-way ANOVA, with test power of $57 \%$, showed there was interaction between the study factors (composite resin and adhesive application).

Tukey test revealed that in the absence of adhesive (groups G1, G2 and G3), the bond strength of the methacrylate-based CR (Filtek ${ }^{\mathrm{TM}} \mathrm{Z} 250$ and Filtek ${ }^{\mathrm{TM}}$ Bulkfill restorative) to the FP was statistically significantly higher, but it did not differ among each other (Table 3).

The bond strength of the silorane-based CR (Filtek ${ }^{\mathrm{TM}}$ P90) specimens was not statistically significantly different from the others when the adhesive was applied. With such treatment, the shear bond strength for Filtek ${ }^{\mathrm{TM}}$ P90 increased significantly while for the other CR the adhesive application did not allow for better performance (Table 3).

For the failure mode, it was noticed that in G2 (Filtek ${ }^{\mathrm{TM}}$ P90) there was predominantly adhesive failures (55\%). When the adhesive for the same CR (G5-silorane adhesive + Filtek $^{\mathrm{TM}}$ P90) was applied, the failures were cohesive in $90 \%$ of the specimens. The same failure mode was most prevalent in all methacrylate-based CR groups when the adhesive was used (G4, $85 \%$ and G6, $70 \%$ ). In G1 (Filtek ${ }^{\mathrm{TM}} \mathrm{Z} 250$ ), mixed failures were predominant (60\%), while in G3 (Filtek ${ }^{\mathrm{TM}}$ Bulkfill restorative), there were adhesive $(45 \%)$ and mixed failures $(40 \%)$ in similar proportions, as noticeable in Graphic 1 (Fig. 7).

Table 3 Average and standard deviation values for shear bond strength of FP, according to technique

\begin{tabular}{|c|c|c|}
\hline \multirow[t]{2}{*}{ Composite Resin } & \multicolumn{2}{|l|}{ Adhesive } \\
\hline & Absent & Present \\
\hline Methacrylate-based resin (Filtek ${ }^{\mathrm{TM}} \mathrm{Z} 250$ ) & $5.54(1.78) \mathrm{Aa}$ & $7.39(2.05) \mathrm{Aa}$ \\
\hline Silorane-based resin (Filtek $\left.{ }^{\mathrm{TM}} \mathrm{P} 90\right)$ & $1.69(1.02) \mathrm{Bb}$ & $6.07(1.88) \mathrm{Aa}$ \\
\hline Methacrylate bulk fill resin (Filtek ${ }^{\mathrm{TM}}$ Bulk Fill) & $5.31(1.58) \mathrm{Aa}$ & $5.50(3.03) \mathrm{Aa}$ \\
\hline
\end{tabular}

Statistical difference is indicated through different capital letters in the row and different small letters in the columns

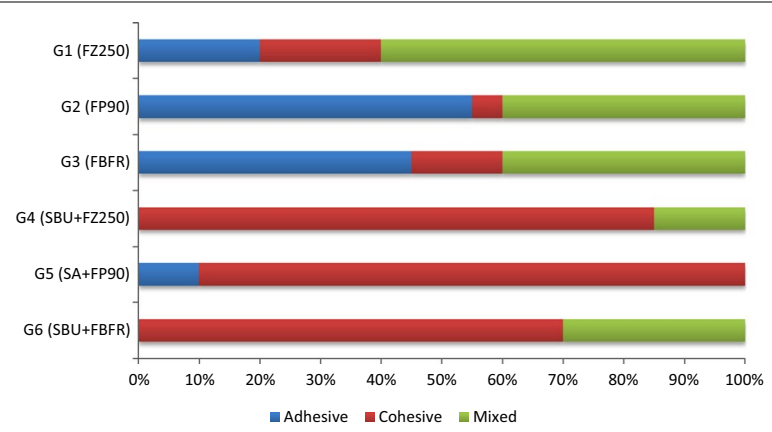

Fig. 7 Graphic 1. Colum diagram of failure mode between FP and CR, with and without adhesive application 


\section{Discussion}

The results of this study rejected the null hypothesis, since the type of CR used and the FP pretreatment with adhesive affected the bond strength between the FP and the CR.

In this study the shear bond strength was tested through a push-out test, seeking similarity to the clinical situation, as the push-out test evaluate a failure that occurs parallel to the adhesive interface $[30,37,38]$. The $2.0 \mathrm{~mm}$ test sample thickness was selected in order to minimize the influence of the $\mathrm{CR}$ fracture resistance in the bond strength of the FP-CR sample tested [39-41].

The use of silane as surface pre-treatment for every group was based on the manufacturer's recommendation and in some literature reports that showed increase in the bond strength of silanized FP $[1,42,43]$. To simplify the methodology of this study, the studies of Rosatto et al. [44] and Novais [45] were considered regarding the use of prehydrolyzed silane and the absence of heat drying, respectively.

Based on recent studies that showed that acid etching does not increase the bond strength [46], but could damage the FP epoxy-matrix [47], this study did not use any etching as FP surface pre-treatment.

A previous study mapped the formation of multiple gaps through the FP-CR interface when no surface treatment was used [2]. On the other hand, Lastumaki [48] showed the positive influence of adhesive usage as surface treatment on the bond strength of FP. In accordance, each CR correspondent adhesive was used.

The present study showed that the type of CR influences the bond strength only when the adhesives were not used as surface treatment, having methacrylate-based resins (FZ250 and FBFR) achieved higher bond strength values ( $<0.05)$ when compared to the silorane-based resin (FP90). This could be related to the difference in polymerization shrinkage between silorane-based resins (lower than $1 \%$ ) and the other CR ( 2 and $5 \%$ [15]. The volumetric reduction that occurs because of cross bonding between the molecules in the CR organic matrix would be reduced in silorane-based CR due to the opening of a cationic ring previously to the formations of such chemical bonds, during the material polymerization $[18,19,49,50]$. It is known that silorane-based CR has significantly lower polymerization shrinkage, although showcasing similar mechanical properties to the methacrylate-based composites [51]. The volumetric decrease (shrinkage) of methacrylate-based composite materials could be responsible for the increase in the push-out bond strength of those materials to the FP through the tightening of the contact between post and CR.

The increase of bond strength when adhesives were applied in this study, only showed statistic significant difference $(\mathrm{p}<0.05)$ between the silorane-based $C R$ groups, which could be explained by the fact that these CR seem to have lower adhesion power to substrate than methacrylate-based CR [52]. In addition, the silorane adhesive system has two phases: one self-etching hydrophilic primer and one hydrophobic resinous adhesive [53].

Despite the shear bond strength showing no statistic difference among the methacrylate-based CR groups, the change in failure mode was noticeable. For all CR groups, when adhesive was not applied, adhesive and mixed failures were predominant for the low-shrinkage CR G2 (Filtek ${ }^{\mathrm{TM}}$ P90) + G3 (Filtek ${ }^{\mathrm{TM}}$ Bulkfill Restorative) and G1 (Filtek $^{\text {TM }}$ Z250) group, respectively, supporting once more the theory that the polymerization 
shrinkage could influence the bond strength due to the increase in the contact between the FP and CR surfaces, which was suggested by Goracci et al. [54].

Furthermore, in all groups that the specific adhesive was applied (G4, G5 and G6), cohesive failure was predominant, which could be supported by the reduction of gaps through the adhesive interface, responsible for initiating mechanical failures and increasing the number of stress points inside the FP-CR sample [32].

The clinical relevance of these findings resides on the fact that adhesive application as surface treatment for personalizing FP could allow for a more safely indication of the customized-post technique, since the failure patterns in this study showed that the FP-CR sample showcased a "one-body" mechanical behavior when the specific adhesive was used.

Further studies are necessary in order to evaluate the in vitro influence of aging in the adhesive interface resistance and whether the positive performance of the adhesivetreated fiber post, especially regarding the failure mode and mechanical behavior, is similar to the performance seeing in this in vitro study.

\section{Conclusions}

Within the limitations of this study, it can be concluded that:

- The use of silorane-based composite resins to customize posts require the use of adhesive as FP surface pretreatment;

- The use of adhesive as pretreatment of simulated customized FP, regardless of the CR used, appear to improve the mechanical behavior of the FP-CR unit;

- The null-hypothesis was discarded, as:

- the bond strength was statistically higher for the methacrylate-based resins without the FP pretreatment with adhesive;

- the FP pretreatment with adhesive increased the bond strength only for the silorane-based resin and changed the prevalence of failure mode type to cohesive in all composite resin study groups.

\section{Abbreviations}

FP: glass fiber post(s); CR: composite resin(s); LED: light emitting diode; MPa: mega pascal; N: Newton; ANOVA: analysis of variance.

\section{Authors' contributions}

PAS carried out all in vitro assays and drafted the manuscript. RTB helped to draft and in revising the manuscript. FA participated in the design of the study. CT performed the statistical analysis. CES conceived of the study and participated in its design. FMF participated in the coordination and helped to draft the manuscript. All authors read and approved the final manuscript.

\section{Author details}

1 São Leopoldo Mandic Institute and Dental Research Center, Rua José Rocha Junqueira, 13, Ponte Preta, Campinas, SP 13045-755, Brazil. ${ }^{2}$ University of the State of Rio de Janeiro, Boulevard 28 de Setembro, 157, Vila Isabel, Rio de Janeiro, RJ 20550-030, Brazil.

Acknowledgements

The authors would like to thank 3M Deutschland GmbH (Seefeld, Germany) for supplying part of the materials used in this study. 
Received: 10 April 2016 Accepted: 1 July 2016

Published online: 11 July 2016

\section{References}

1. Aksornmuang J, Foxton RM, Nakajima M, Tagami J. Microtensile bond strength of a dual-cure resin core material to glass and quartz fiber posts. J Dent. 2004;32(6):443-50.

2. Sadek FT, Monticelli F, Goracci C, et al. Bond strength performance of different resin composites used as core materials around fiber posts. Dent Mater J. 2007;23(1):95-9.

3. Perdigão J, Gomes G, Augusto V. The effect of dowel space on the bond strengths of fiber posts. J Prosthodont. 2007;16(3):154-64.

4. Schmage P, Pfeiffer P, Pinto E, et al. Influence of oversized dowel space preparation on the bond strengths of frc posts. Oper Dent. 2009;34(1):91-101.

5. Gomes GM, Rezende EC, Gomes OMM, et al. Influence of the resin cement thickness on bond strength and gap formation of fiber posts bonded to root dentin. J Adhes Dent. 2014;16:71-8.

6. D'Arcangelo C, Cinelli M, De Angelis F, D'Amario M. The effect of resin cement film thickness on the pullout strength of a fiber-reinforced post system. J Prost Dent. 2007;98(3):193-8.

7. Tey KC, Lui JL. The effect of glass fiber-reinforced epoxy resin dowel diameter on the fracture resistance of endodontically treated teeth. J Prosthodontic. 2014;23:572-81.

8. Sivieri-Araujo $\mathrm{G}$, et al. Fracture resistance of simulated immature teeth after different intra-radicular treatments. Braz Dent J. 2015;26(3):211-5.

9. Sharafeddin F, Alavi AA, Zare S. Fracture resistance of structurally compromised premolar roots restored with single and accessory glass or quartz fiber posts. Dent Res J (Isfahan). 2014;11(2):264-71.

10. Boksman L, Hepburn AB, Kogan E, et al. Fiber post techniques for anatomical root variations. Dent Today. 2011:30(5):106-11.

11. Costa RG, Morais ECC, Leão MP, Bindo MJF, Campos EA, Correr GM. Three-year follow up of customized glass fiber esthetic posts. Europ J Dent. 2011;5:107-12.

12. Savi A, Manfredi M, Tamani M, Fazzi M, Pizzi S. Use of customized fiber posts for the aesthetic treatment of severely compromised teeth: a case report. Dent Traumatol. 2008;24:671-5.

13. Zogheib LV, Saavedra GSFA, Cardoso PE, Valera MC, Araujo MAM. Resistance to compression of weakened roots subjected to different root reconstruction protocols. J Appl Oral Sci. 2011;19(6):648-54

14. Saygili G, Sahmali SM. Comparative study of the physical properties of core materials. Int J Periodontics Restor Dent. 2002;22(4):355-63.

15. Mendoza DB, Eakle WS, Kahl EA, et al. Root reinforcement with a resin-bonded preformed post. J Prosthet Dent. 1997;78(1):10-5

16. Combe EC, Shaglouf A, Watts DC, et al. Mechanical properties of direct core build-up materials. Dent Mater. 1999;15:158-65

17. Labella R, Lambrechts P, Van Meerbeek B, Vanherle G. Polymerization shrinkage and elasticity of flowable composites and filled adhesives. Dent Mater. 1999;15:128-37.

18. Weinmann W, Thalacker C, Guggenberger R. Siloranes in dental composites. Dent Mater J. 2005;21(1):68-74

19. Duarte JS, Botta AC, Phark JH, Sadan A. Selected mechanical and physical properties and clinical application of a new low-shrinkage composite restoration. Quintessence Int. 2009;40(8):631-8.

20. Ilie N, Hickel R. Investigations on a methacrylate-based flowable composite based on the SDR ${ }^{\mathrm{TM}}$ technology. Dent Mater. 2011;27:348-55.

21. Hernandes NMAP, Catelan A, Soares GP, et al. Influence of flowable composite and restorative technique on microleakage of class II restorations. J Invest Clin Dent. 2013;4:1-6.

22. Fleming GJ, Awan M, Cooper PR, Sloan AJ. The potential of a resin-composite to be cured to a $4 \mathrm{~mm}$ depth. Dent Mater J. 2008;24:522-9.

23. Roggendorf MJ, Krämer N, Appelt A, et al. Marginal quality of flowable 4-mm base vs. conventionally layered resin composite. J Dent. 2011;39:643-7.

24. Akkayan B, Gülmez T. Resistance to fracture of endodontically treated teeth restored with different post systems. J Prosth Dent. 2002;87(4):431-7.

25. Rathke A, Haj-Omer D, Muche R, et al. Effectiveness of bonding fiber posts to root canals and composite core buildups. Eur J Oral Sci. 2009:117:604-10.

26. Koch AT, Binus SM, Holzschuh B, Petschelt A, Powers JM, Berthold C. Restoration of endodontically treated teeth with major hard tissue loss-influence of post surface design on pull-out bond strength of fiber-reinforced composite posts. Dent Traumatol. 2014;30(4):270-9.

27. Carvalho CA, Breschi L, Navarro MF, et al. Push-out bond strength and SEM evaluation of a new bonding approach into the root canal. J Appl Oral Sci. 2012;20(6):613-9.

28. Salameh Z, Papacchini F, Ounsi HF, Goracci C, Tashkandi E, Ferrari M. Adhesion between prefabricated fiberreinforced posts and different composite resin cores: a microtensile bond strength evaluation. J Adhes Dent. 2006:8(2):113-7.

29. Debnath S, Wunder SL, McCool Jl, Baran GR. Silane treatment effects on glass/resin interfacial shear strengths. Dent Mater. 2003;19:441-8.

30. Elsaka SE. Influence of chemical surface treatments on adhesion of fiber posts to composite resin core materials. Dent Mater J. 2013;29:550-8.

31. Leme AA, et al. Effects of silane application on luting fiber posts using self-adhesive resin cement. J Adhes Dent. 2013;15(1):269-74. 
32. Vano M, Goracci C, Monticelli F, et al. The adhesion between fiber posts and composite resin cores: the evaluation of microtensile bond strength following various surface chemical treatments to posts. Inter Endo Journal. 2006;39:31-9.

33. Costa RG, De Morais EC, Campos EA, Michel MD, Gonzaga CC, Correr GM. Customized fiber glass posts. Fatigue and fracture resistance. Am J Dent. 2012;25(1):35-8.

34. Bosso K, Júnior AG, Guiraldo RD, Berger SB, Lopes MB. Stress generated by customized glass fiber posts and other types by photoelastic analysis. Braz Dent J. 2015;26(3):222-7.

35. Anche S, Kakarla P, Kadiyala KK, Sreedevi B, Chiramana S, Dev JRR, Manne SD, Deepthi G. The comparison of shear bond strength between fiber reinforced composite posts with three different composite core materials - an in vitro study. J Clin Diagnost Res. 2014;8(1):236-8.

36. Shori D, Pandey S, Kubde R, Rathod Y, Atara R, Rathi S. To evaluate and compare the effect of different post surface treatments on the tensile bond strength between fiber posts and composite resin. J Int Oral Health. 2013;5(5):27-32

37. Cekic-Nagas I, Sukuroglu E, Canay S. Does the surface treatment affect the bond strength of various fiber-post systems to resin-core materials? J Dent. 2011;39(2):171-9.

38. Cekic-Nagas I, Ergun G, Nagas E, Tezvergil A, Vallittu PK, Lassila LV. Comparison between regional micropush-out and microtensile bond strength of resin composite to dentin. Acta Odontol Scand. 2008;66(2):73-81.

39. Arslan H, Barutcigil C, Yılmaz CB, Ceyhanlı KT, Topcuoglu HS. Push-out bond strength between composite core buildup and fiber-reinforced posts after different surface treatments. Photomed Laser Surg. 2013;31 (7):328-33.

40. Das AK, Muddugangadhar BC, Amarnath GS, Garg A, Kumar U, Rao TR. Comparative evaluation of push out bond strength of a fiber post system using four different resin cements: an in vitro study. J Int Oral Health. 2015;7(Suppl 1):62-7.

41. Kadam A, Pujar M, Patil C. Evaluation of push-out bond strength of two fiber-reinforced composite posts systems using two luting cements in vitro. J Conserv Dent. 2013;16:444-8.

42. Goracci C, Rafaelli O, Monticelli F, Balleri B, Bertelli E, Ferrari M. The adhesion between prefabricated FRC posts and composite resin cores: microtensile bond strength with and without post-silanization. Dent Mater. 2005;21(5):437-44.

43. Perdigão J, Gomes G, Lee IK. The effect of silane on the bond strengths of fiber posts. Dent Mater. 2006;22:752-8.

44. Rosatto CMP, Roscoe MG, Novais VR, Menezes MS, Soares CJ. Effect of silane type and air-drying temperature on bonding fiber post to composite core and resin cement. Braz Dental J. 2014;25(3):217-24.

45. Novais VR, Simamoto Junior PC, Rontani RMP, Correr-sobrinho L, Soares CJ. Bond strength between fiber posts and composite resin core-influence of temperature on silane coupling agents. Braz Dent J. 2011;23(1):8-14.

46. Bergoli CD, Amaral M, Boaro LC, Braga RR, Valandro LF. Fiber post cementation strategies: effect of mechanical cycling on push-out bond strength and cement polymerization stress. J Adhes Dent. 2012;14(5):471-8.

47. Güller AU, Kurt M, Duran I, Uludamar A, Inan O. Effects of different acids and etching times on the bond strength of glass fiber-reinforced composite root canal posts to composite core material. Quint Int. 2012;43(1):1-8.

48. Lastumäki TM, Kallio TT, Vallittu PK. The bond strength of light-curing composite resin to finally polymerized and aged glass fiber-reinforced composite substrate. Biomaterials. 2012;23:4533-9.

49. Palin WM, Fleming GJP, Burke FJT, et al. The influence of short and medium-term water immersion on the hydrolytic stability of novel low-shrink dental composites. Dent Mater J. 2005;21(9):852-63.

50. Ilie N, Hickel R. Silorane-based dental composite: behavior and abilities. Dent Mater J. 2006;25(3):445-54.

51. Arrais CAG, Oliveira MTD, Mettenburg D, et al. Silorane and high filled-based "low-shrinkage" resin composites: shrinkage, flexural strength and modulus. Braz Oral Res. 2013;27(2):91-102.

52. Ozer S, Tunc ES, Gonulol N. Bond strengths of silorane- and methacrylate-based composites to various underlying materials. BioMed Res Inter. 2004;1-6:10.

53. Mine A, et al. TEM characterization of a silorane composite bonded to enamel/dentin. Dent Mater J. 2010;26(6):524-32.

54. Goracci C, Fabianelli A, Sadek FT, Papacchini F, Tay FR, Ferrari M. The contribution of friction to the dislocation resistance of bonded fiber posts. J Endod. 2005;31(8):608-12.

\section{Submit your manuscript to a SpringerOpen ${ }^{\circ}$ journal and benefit from:}

- Convenient online submission

- Rigorous peer review

Immediate publication on acceptance

- Open access: articles freely available online

- High visibility within the field

- Retaining the copyright to your article

Submit your next manuscript at $\boldsymbol{\nabla}$ springeropen.com 